\title{
Students’ Entrepreneurial Propensity: An Exploratory Study from a Portuguese Polytechnic School
}

\section{Silva $A^{1 *}$ and Nobre $\mathbf{N}^{2}$}

${ }^{1}$ Department of Economics and Management, Polytechnic Institute of Porto-ISCAP, Portugal

${ }^{2}$ Institute of Porto-ESEIG, Portugal

\begin{abstract}
Given the high unemployment among young and well educated people, entrepreneurial initiatives may turn to be valid actions to mitigate such difficulties. High education schools can contribute to detect and support students with potential to become young entrepreneurs and they also can involve and inspire other students.

In the sequence of a branch of research into student entrepreneurship that has been developed in recent years, the aim of this study is two-fold: firstly, to estimate the entrepreneurial propensity of students at a Portuguese polytechnic school and, secondly, to evaluate the importance of academic, personal and contextual factors that may be explanatory factors to this propensity. The present study is based on a sample of 277 students who were, at the time of the research (2013), enrolled in a Master's degree or in a Bachelor's degree.

The results obtained suggest, at one hand, that student from management areas and students from more advanced curricular years present higher propensity to entrepreneurship but also, on the other hand, that knowing entrepreneurs examples and having previous management experiences potentiate such propensity, thus confirming the usefulness of higher connections between academia and firms.
\end{abstract}

Keywords: Students; Entrepreneurial propensity; Tertiary education

\section{Introduction}

During the last few years, some governments and educational entities have revealed a special interest in the link between activities related to promote entrepreneurship and young people with higher education. Much of this interest arises from the general agreement that entrepreneurial initiatives contribute significantly to economic development and for job creation, which is especially relevant when there is such a high unemployment among the young population $[1,2]$.

In fact, considering the huge level of unemployment among young graduates and knowing that the entrepreneurship of young graduates can be a way to mitigate this scourge, the role of educational institutions becomes crucial in creating and shaping an entrepreneurial attitude. Nevertheless, not all students act in the same way when faced with the possibility of becoming entrepreneurs and this happens because some of the entrepreneurship decisions are related to psychological and personal temperament factors. Accordingly, there is uncertainty regarding the type of factors that can influence (in a positive or negative way) each and every student's entrepreneurial propensity $[3,4]$.

Our work aims to assess and enhance the entrepreneurial propensity of the students of ESEIG, which is an organic unit of the Porto Polytechnic Institute. From a global survey of all the school's students, we use the answers of 277 students which were attending a course in this school. The study also aims to understand what factors can enhance or delay entrepreneurial propensity and what role the school can play in this respect.

Complementarily, taking into consideration the results of the European Commission Report [5] stating that entrepreneurial education is mainly provided by university courses in business sciences, we study the relationship between entrepreneurial propensity and the nature of the courses offered by ESEIG.

In short, the main questions that need to be answered are: "What is the ESEIG student's entrepreneurial propensity and what are the intrinsic and/or extrinsic factors that have the greatest influence on the surveyed student's propensity?"

This article is divided into four sections. Following this introduction, in the second section, we present a brief literature review in order to explore some concepts and also to explain the factors that many authors consider may have more impact on entrepreneurial propensity. In section three, the database and the methodology used to evaluate student's entrepreneurial propensity are described and in the fourth section the results of the survey and of the logistic regression model are presented. Finally, the main conclusions are displayed.

\section{Literature Review}

Variables and factors that influence general entrepreneurial propensity

There are many perspectives and studies about which factors decisively influence new entrepreneurial initiatives. The main variables mentioned are socio-demographic factors, perceptual variables, economic and social factors, motivational factors, environmental and some additional factors [6].

Socio-demographic factors such as gender, age, level of education or job situation can be used to explain the existing entrepreneurial potential. However, these factors are not so influential as to predict the choice of professional career [7].

*Corresponding author: Silva A, Assistant Professor, Department of Economics and Management, Polytechnic Institute of Porto-ISCAP, Portugal, Tel: +351229050000; E-mail: armandosilva@eu.ipp.pt

Recieved December 30, 2017; Accepted February 08, 2018; Published February 13, 2018

Citation: Silva A, Nobre N (2018) Students' Entrepreneurial Propensity: An Exploratory Study from a Portuguese Polytechnic School. J Entrepren Organiz Manag 7: 226. doi: 10.4172/2169-026X.1000226

Copyright: (c) 2018 Silva A, et al. This is an open-access article distributed under the terms of the Creative Commons Attribution License, which permits unrestricted use, distribution, and reproduction in any medium, provided the original author and source are credited. 
In another perspective, Arenius and Minniti [6] describe perceptual variables as individual beliefs that do not reflect objective facts. This is the case of the opportunity perception [8], the trust in one's own capacities or lack of control [9], the expected gain [3], the fear of failure, the propensity/aversion to risk [10] or the example of other entrepreneurs [9].

As far as motivational factors are concerned, McClelland [11] recognized the importance of each person's personal traits as possible explanatory factors of the entrepreneurial propensity: realization need, affiliation need or the need for power. Since then, several studies have been developed, adding new personal traits and characteristics that may influence entrepreneurial propensity, such as: opportunity perception [12], intention and/or capacity [13], monetary factors and independence [14], search for opportunity, trust in skills, lack of responsibility, entrepreneurial motivation and fears related to entrepreneurship [15].

Shapero [16] was one of the first to investigate the relationship between environmental variables and entrepreneurship. Factors such as country trend (economic cycle), availability of funds, and existence of standard firms used as role models revealed a strong connection with entrepreneurship. Castrogiovanni [17] concluded that the performance of recently established companies varies according to: macroeconomic uncertainty, lack/availability of resources and practical business knowledge. Robertson [18] highlights the importance of consulting services, credit access, family and friends' support and networking to entrepreneurial propensity. Also in this respect, Gnyawali and Fogel [19] state that the importance of environmental factors differs from country to country.

\section{Student's entrepreneurial propensity: global characterization}

In addition to the literature that studies the general determinants of entrepreneurship, there are two connected branches that study, at one hand, what determines the entrepreneurial propensity of higher education student and, at the other hand, the productivity of entrepreneurial education vis-à-vis stimulating the supply of entrepreneurs into society in particular.

For the first of those branches there is a rich and recent literature trend; for instance, Franke and Franke and Lüthje [20] analyzed the personality traits of 850 students at three Universities (Munich, Vienna and Massachusetts) and the perception of their contextual factors in order to understand the international differences of the students' entrepreneurial propensity. The data obtained revealed different entrepreneurial intentions (Munich: 25.4\%, Vienna: 36.2\% and Massachusetts: 49.6\%). Factors such as capital market development, governmental policies towards firm creation or the university's role (in initial projects, dissemination of entrepreneurial practices and promoting networking among students) revealed higher explanatory weight in the trend for student's entrepreneurship.

Gürol and Atsan [21] analyzed 400 Turkish students in the $4^{\text {th }}$ year of two Universities and concluded, via a survey, that the assumption to take risks, the ability to control, personal realization and the taste for innovation were the main factors that led students to entrepreneurship.

After implementing a survey of 1000 students in universities in England and Ireland, Scott and Twomey [22] noticed that the students who already had a business idea were more likely to create new firms than the others. The fact that the students have parents related to entrepreneurship was also very important. Moreover, students with professional experience and with good business perception and a clear idea were the most likely to set up firms. These entrepreneurs were also lovers of such values as: independence, innovation capacity and autonomy. In fact, in a complementary study, Wang and Wong [23] emphasized the idea that lack of preparation and business knowledge were the main factors preventing the creation of businesses.

More recently, Fafaliou [24] used a sample of 364 students at a Greek university to study the impact of demographic, motivational, perceptual and other factors on student's entrepreneurial propensity. On the one hand, the risk propensity was the most significant of all the motivational factors; on the other hand, all the demographic factors were considered important in the influence on students (professional experience, personal experience in leadership, family entrepreneurial background, and gender and formation background). The author concluded that $34.7 \%$ of the people surveyed had a clear idea of business and $46.5 \%$ were willing to create their own business. However, inadequate preparation, difficulties in the start-up phase, lack of capital and market conditions or bureaucracy were statistically relevant and influenced, in a negative way, the students' tendency towards entrepreneurship.

Meanwhile, there is a different literature branch studying the efficiency of higher education in promoting the creation of new firms. In this respect, some authors [25] cast some doubts on such ability of higher education to promote entrepreneurship ventures, while others believe higher education in general, and entrepreneurship education in particular, may be key instruments to help promote entrepreneurial activity [26].

\section{Studies in Portugal on students' entrepreneurial propensity}

Rosario [27] evaluated the final year students' entrepreneurial propensity at Oporto University. In this way, and through a survey applied to 14 Universities, the author obtained an average rate of student propensity of $26.5 \%$. Curiously, students from areas traditionally identified as more "entrepreneurial" (Economics, Management and Technology) had the least propensity. Considering all the students in their final year (2423), the study concluded that about $56 \%$ of the potential entrepreneurs were females and had an average age of 23 . Most of the population (80\%) were full-time students and lived in the North region. Just a small percentage of the population $(7.7 \%)$ was considered to be risk tolerant and $36.1 \%$ of the population surveyed presented leadership traits. Although $51.5 \%$ of the students had chosen to invest in high-tech, with a view to possibly creating their own business, only $14.2 \%$ were willing to invest in creative companies. More than half of the students had an entrepreneur relative in their family.

Gerry et al. [7] also applied a similar study, over 640 students from the University of Vila Real. The authors concluded that the students entrepreneurial propensity was close to $24 \%$. Once again, inadequate preparation was a barrier to business start-ups. Gender, risk propensity, career choice and academic preparation were the most relevant factors. The authors also verified that, in spite of the predominance of females in the sample, males showed greater propensity to establish their own business. The aversion to risk continues to be the most important of the psychological factors.

\section{Database and Methodology}

\section{Survey and description}

The data was collected in March and April (in the academic year of 2012/2013) by implementing an online survey. The survey gathered an overall response rate of $20.40 \%$; we found the data obtained as representative of the population (Table 1). 


\begin{tabular}{|c|c|c|c|c|c|}
\hline Gender & $\begin{array}{l}\text { Number of answers } \\
\text { (1) }\end{array}$ & $\begin{array}{l}\% \text { of answers } \\
\text { (2) }\end{array}$ & $\begin{array}{l}\text { Whole Population } \\
\text { (3) }\end{array}$ & $\begin{array}{l}\% \text { of population } \\
\text { (4) }\end{array}$ & $\begin{array}{c}\text { Answers representation } \\
(5)=(1) /(3)\end{array}$ \\
\hline Female & 169 & $61 \%$ & 795 & $57 \%$ & \\
\hline Male & 108 & $39 \%$ & 632 & $43 \%$ & \\
\hline \multicolumn{6}{|l|}{ Academic year } \\
\hline 1 & 111 & $40 \%$ & 721 & $50 \%$ & $15 \%$ \\
\hline 2 & 90 & $32 \%$ & 364 & $26 \%$ & $25 \%$ \\
\hline 3 & 76 & $28 \%$ & 342 & $24 \%$ & $22 \%$ \\
\hline \multicolumn{6}{|l|}{ Age } \\
\hline$<21$ & 118 & $43 \%$ & 546 & $38 \%$ & $22 \%$ \\
\hline $21-24$ & 45 & $16 \%$ & 388 & $27 \%$ & $13 \%$ \\
\hline $25-29$ & 50 & $18 \%$ & 190 & $13 \%$ & $26 \%$ \\
\hline $30-39$ & 47 & $17 \%$ & 221 & $15 \%$ & $21 \%$ \\
\hline$>40$ & 17 & $6 \%$ & 82 & $6 \%$ & $20 \%$ \\
\hline \multicolumn{6}{|l|}{ Professional situation } \\
\hline Full-time student & 195 & $71 \%$ & 1135 & $75 \%$ & $17 \%$ \\
\hline Working student with status & 80 & $29 \%$ & 292 & $25 \%$ & $28 \%$ \\
\hline \multicolumn{6}{|l|}{ Course } \\
\hline Undergraduate degrees & 188 & $67 \%$ & 1167 & $81 \%$ & $16 \%$ \\
\hline Master's & 82 & $30 \%$ & 182 & $14 \%$ & $45 \%$ \\
\hline Postgraduate & 7 & $3 \%$ & 78 & $5 \%$ & $9 \%$ \\
\hline
\end{tabular}

Table 1: Sample and population characterization.

This process was undertaken in cooperation with ESEIG's Academic Services, course coordinators and course and classroom delegates.

The students responded to 26 questions, including: sociodemographic characterization (gender, age, residence), academic characterization (course and academic year), professional experience and aspirations, level of self-assessment on risk propensity, will and possibility of future business creation, family background on entrepreneurship, personal experience in international school exchanges (ERASMUS) and knowledge of the existence of an office to support entrepreneurship in school. In the following sections of the survey, students indicated their own perception of the importance of motivational, contextual and other factors that might influence (positively or negatively) the business start-up trend.

Specifically, in order to evaluate students' propensity (the dependent variable of the study), we used the answers to two different questions: firstly, we used the question:

"Would you be able to create your own business?" secondly we used the question: "Have you a clear idea for a new business?"

For the first question there were four possible answers:

a) Yes; b) No; c) Maybe in the future; d) already did/I'm creating it.

In the statistical study it was considered that points (a) and (d) would be a clear indication of entrepreneurial propensity by the students surveyed; on the other hand, answers (b) and (c) were indicative of non-entrepreneurial propensity and were therefore added as negative answers.

For the second question, there were three possible answers:

a) Yes; b) No; c) I am not sure.

In the statistical study it was considered that only answer (a) would be a clear indication of entrepreneurial propensity by the students surveyed.

\section{Descriptive analysis}

From the whole set of answers we highlight the following Table 1: the percentage of females (with $61 \%$ of observations, against $39 \%$ from the males), most of the answers were from students up to twenty-one years old (43\%), most of the population (58.5\%) was composed of fulltime students ( $41.5 \%$ were working students). Meanwhile, $68.2 \%$ of the sample was enrolled in undergraduate courses and $31.8 \%$ in Master's Degrees.

The courses with a higher percentage of answers were Accountancy and Administration (21.7\%), Human Resources (14.4\%), Hotel Administration (8.7\%) and Industrial Engineering and Management (7.2\%), and for the Master's Degrees Business Finances (13\%), Industrial Engineering and Management (7.6\%) and Corporate Information (4.7\%).

Of the 277 students in the sample, $74.7 \%$ came from the Oporto district, $14.8 \%$ from Braga and $4.7 \%$ from Aveiro. The students were also asked to indicate their place of residence outside the school period in order to observe whether they lived in urban or non-urban centers; the results were: $74 \%$ lived in urban centers and $26 \%$ outside urban centers. Looking to the future, $72.2 \%$ of the sample students see themselves as dependent workers and $83.4 \%$ of those $72.2 \%$ would like to work in the private sector. Approximately $58 \%$ already revealed some contact with professional life.

232 students $(83.8 \%)$ indicate that school training is a determining factor in finding a future job in an area of interest. With regard to the role of specific entrepreneurial education, $76.2 \%$ claim it to be important in creating a new business. However, $46.9 \%$ consider that college does not provide the necessary groundwork to become a possible entrepreneur. Of the surveyed students, 195 (70.4\%) would like to see more curricular units oriented towards entrepreneurship in their courses, while 62 (22.4\%) think that these courses already possess enough curricular units in their study plans devoted to entrepreneurship.

Nevertheless, the main question of this paper relates to the entrepreneurial propensity of higher education students and our results are even higher than those obtained in Portuguese high schools by Gerry et al. [7] and Rosario [27]. In fact, using the first measure, $30.3 \%$ of the students considered they able to create their own business, while $4.3 \%$ had already created one and $59.9 \%$ indicated the possibility of doing so 
in the near future. Thus, $35 \%$ of the students respond in a positive way when asked about the predisposition of creating a new business (this percentage is the total of "yes" and "already did" answers). Meanwhile, using the second measure of potential entrepreneurship we found that almost $40 \%$ of the students had a clear idea for future business creation.

In spite of the encouraging results, the fact is that $52 \%$ of the students revealed that they had no clear idea about the specific business they want to create. Among the students who already had such ideas, Services, Consultants and Retail Sectors were the most mentioned. Even so, $71.5 \%$ of those surveyed had done nothing in the past 12 months to help create such a business (for instance, finding a location, finding specific equipment, organizing a team, working on a business plan, saving). At another level, most of the students mentioned some personal and external limitations to the creation of new businesses ( $82.31 \%$ and $94.22 \%$, respectively); aspects such as practical knowledge of the business, inadequate preparation and lack of resources were most commonly pointed out as barriers. Relative to risk propensity, the two extreme degrees of acceptance and negation were the ones with the lowest rates of response (7.59\%). In fact, between the options "risk aversion" and "willing to take risks" the difference is minimal and the responses are quite divided: $51.62 \%$ of students show risk propensity to create a business [28].

In the second part of the questionnaire, the students had to evaluate the level of importance of various factors known as barriers or boosters of entrepreneurship. Of the motivational factors, the realization of own ideas and the recognition of an opportunity in the market were the most indicated as business creation enhancers; success and prestige were the least important. Access to finance and the current economic crisis were the most important barriers to business creation among the external factors.

\section{Statistic model estimation: regression analysis}

After the data collection, we moved on to the next phase and the results were tested using the econometric STATA software. Considering that the main goal of this study was to evaluate the level of entrepreneurial propensity among ESEIG students and the importance of the main factors that can explain that propensity and their influence, we started by evaluating the level of correlation between the set of variables available (Table 2).

The dependent variable is related to the question: "Would you be able to create your own business?" where the answers Yes/Already $\operatorname{did}=1$ and No/Maybe=0. Due to the type of possible answer to this question, the choice of econometric model to be adopted was the logistic regression or logit model. Given that fact, conventional estimation techniques (e.g., multiple regression analysis) in this context of a discrete dependent variable are not a valid option; on the one hand, the assumptions needed for hypothesis testing in conventional regression analysis are violated (it is unreasonable to assume, for instance, that the distribution of errors is normal); on the other hand, there are a lot of factors that can influence the student's probability of becoming an entrepreneur that other conventional techniques could not tell, because some values cannot be converted into probabilities, which means they cannot be expressed in an interval between 0 and 1 . Thus, the student's entrepreneurial propensity is estimated according to the following logistic regression:

$\mathrm{P}$ (entrepreneur) $=1 /\left(1+\mathrm{e}^{(-\mathrm{Z})}\right)$

Rewriting the equation considering the probabilities, we have:

Log (Entrepreneur Prob)/ (Non-Entrepreneur Prob) $=\beta 0+\beta 1$ Gender $+\beta 2$ Age $+\beta 3$ Urban $+\beta 4$ Master $+\beta 5$ Course $+\beta 6$ Year $+\beta 7$ Status $+\beta 8 \quad$ Example $+\beta 9 \quad$ Chief $+\beta 10 \quad$ Erasmus $+\beta 11$ Personal $+\beta 12$ External $+\beta 13$ Risk $+\varepsilon$ i.

The logistic coefficient can be interpreted by the change in the log odds associated with a one-unit change in the independent variable; thus, it is the change in the logarithm of the student's probability of becoming an entrepreneur (with the relationship of the probability of non-becoming) when a one-unit change occurs in the independent variable $\beta \mathrm{i}$.

In practice, the exponential raised to the power $\beta \mathrm{i}$ corresponds to the factor by which such relative probability changes, when the independent variable increases by one unit. If $\beta \mathrm{i}$ is positive, this factor will be higher than 1 , which means that the relative probability increases. If $\beta \mathrm{i}$ is negative, the factor will be less than 1 , which means that the relative probability decreases. When $\beta$ i equals 0 , the factor equals 1, which does not affect the relative probabilities. Exemplifying with the first independent variable, if $\beta_{1}=1=$ Male) is positive and presents statistical significance, this means that, on average, ceteris paribus, being a male student increases the relative probability of finding students with entrepreneurship propensity.

\section{Results}

Analyzing the results from Table 3, we conclude that of the 13

\begin{tabular}{|c|c|c|c|c|c|c|c|c|c|c|c|c|c|}
\hline & 1 & 2 & 3 & 4 & 5 & 6 & 7 & 8 & 9 & 10 & 11 & 12 & 13 \\
\hline 1 & 1.00 & & & & & & & & & & & & \\
\hline 2 & 0.19 & 1.00 & & & & & & & & & & & \\
\hline 3 & 0.07 & 0.18 & 1.00 & & & & & & & & & & \\
\hline 4 & 0.09 & 0.29 & 0.15 & 1.00 & & & & & & & & & \\
\hline 5 & -0.04 & -0.19 & -0.07 & -0.02 & 1.00 & & & & & & & & \\
\hline 6 & 0.01 & 0.00 & -0.09 & -0.37 & -0.01 & 1.00 & & & & & & & \\
\hline 7 & 0.18 & 0.59 & 0.15 & 0.41 & -0.17 & -0.09 & 1.00 & & & & & & \\
\hline 8 & -0.02 & -0.00 & 0.08 & 0.06 & 0.09 & -0.04 & 0.02 & 1.00 & & & & & \\
\hline 9 & 0.00 & 0.02 & 0.04 & -0.02 & 0.18 & 0.13 & 0.03 & 0.20 & 1.00 & & & & \\
\hline 10 & 0.05 & -0.05 & 0.06 & 0.09 & 0.06 & -0.07 & 0.01 & 0.01 & 0.01 & 1.00 & & & \\
\hline 11 & -0.02 & 0.03 & 0.03 & -0.03 & 0.10 & 0.02 & 0.02 & -0.04 & -0.01 & 0.02 & 1.00 & & \\
\hline 12 & -0.02 & -0.09 & 0.14 & 0.00 & -0.06 & 0.08 & 0.02 & 0.11 & -0.03 & -0.01 & 0.13 & 1.00 & \\
\hline 13 & 0.16 & -0.07 & -0.13 & -0.08 & -0.05 & 0.16 & 0.04 & 0.00 & 0.10 & 0.05 & -0.13 & 0.02 & 1.00 \\
\hline
\end{tabular}

Legend: 1-Gender, 2-Age, 3-Urban, 4-Master's course, 5-Course, 6-Curricular year, 7-Working student, 8-Example, 9- Manager, 10- Erasmus, 11- Personal limitations, 12- External limitations, 13- Risk.

Table 2: Statistical correlations 
factors included in the regression analysis, 8 are statistically significant when we use the first measure of entrepreneurial propensity (Gender, Age, Course, Curricular Year, Entrepreneur Example, Manager, Erasmus and Risk) and 5 are not (Urban Centre, Master's, Working Status, Personal limitations and External limitations). When the second measure of entrepreneurial propensity is used, there are 6 significant factors (Gender, Age, Course, Entrepreneur Example, Manager and Risk) (Table 3).

\section{Notes}

Moreover, being male (Gender=1) increases the relative likelihood of students becoming entrepreneurs. Considering everything else to be constant and using the first measure of entrepreneurship propensity, if a student is a male, this condition multiplies the relative probability of entrepreneurship by $170 \%$ (exp ${ }^{0.53}=1.7$ ). With regard to the age factor, by the time the student becomes a year older, ceteris paribus, it multiplies the relative likelihood of becoming a possible entrepreneur by $104 \%$.

However, students from higher years show less entrepreneurial propensity, which means that the transition of one curricular year decreases the relative likelihood by $61 \%$. The double consideration of these contradictory facts enhances the explicative weight of the year transition as a factor that reduces entrepreneurial propensity. A possible explanation for this fact results from the increasing awareness of the difficulties of entrepreneurship that students from higher curricular years obtain.

Meanwhile, to evaluate the importance of the course areas to entrepreneurial propensity, the courses were classified on a numerical scale from 1 to 9 following a decreasing importance of management in the structure of those courses.

Of all the courses, the students from Accounting and Administration, Corporate Finances and Hotel Management were the most likely future entrepreneurs; while students from Biomedical Engineering, Mechanical Engineering and Library and Information Sciences and Technologies were the ones with the lowest propensity for new business creation. The estimations show that the relative likelihood decreases when we stop considering students from the first group of courses and replace them progressively with courses with less connection to Management/ Business Sciences and where no curricular units study entrepreneurship issues.

Complementarily, the experience of being a previous manager multiplies the relative probability of entrepreneurship by $163 \%$; also the experience in exchange programs (Erasmus) and family examples of entrepreneurship increase the relative probability of entrepreneurship. Last but not least, risk aversion, shows that the transition of a riskadverse student to a risk-willing student increases substantially the relative likelihood of entrepreneurship by $400 \%\left(\exp ^{1.41=} 4\right)$.

\section{Conclusions}

This study aimed to assess ESEIG students' entrepreneurial propensity and to find the importance of course specificities, personal and external factors that could explain entrepreneurial propensity. We used data from a representative survey applied to ESEIG students and we obtained an overall entrepreneurial propensity between $35 \%$

\begin{tabular}{|c|c|c|}
\hline Factor & $\begin{array}{c}\text { First measure } \\
\text { Coefficient (robust standard error) }\end{array}$ & $\begin{array}{l}\text { Second measure } \\
\text { Coefficient (robust standard error) }\end{array}$ \\
\hline Gender & $\begin{array}{l}0.531^{* * *} \\
(0.285)\end{array}$ & $\begin{array}{l}0.433^{\text {t*t }} \\
(0.185)\end{array}$ \\
\hline Age & $\begin{array}{l}0.044^{*} \\
(0.021)\end{array}$ & $\begin{array}{l}0.039^{* *} \\
(0.019)\end{array}$ \\
\hline Urban resident & $\begin{array}{c}0.433 \\
(0.337)\end{array}$ & $\begin{array}{c}0.533 \\
(0.337)\end{array}$ \\
\hline Master's & $\begin{array}{l}-0.185 \\
(0.342)\end{array}$ & $\begin{array}{l}-0.097 \\
(0.242)\end{array}$ \\
\hline Course & $\begin{array}{l}-0.087^{+* * *} \\
(0.046)\end{array}$ & $\begin{array}{l}-0.095^{* * *} \\
(0.045)\end{array}$ \\
\hline Curricular year & $\begin{array}{l}-0.491^{*} \\
(0.206)\end{array}$ & $\begin{array}{r}-0.4385 \\
(0.248)\end{array}$ \\
\hline Working student & $\begin{array}{l}-0.122 \\
(0.352)\end{array}$ & $\begin{array}{c}0.092 \\
(0.145)\end{array}$ \\
\hline Examples & $\begin{array}{c}0.57^{\star \star \star} \\
(0.371)\end{array}$ & $\begin{array}{c}0.47^{\star *} \\
(0.384)\end{array}$ \\
\hline Leadership & $\begin{array}{c}0.49^{* * *} \\
(0.304)\end{array}$ & $\begin{array}{c}0.59^{* \star *} \\
(0.298)\end{array}$ \\
\hline Erasmus & $\begin{array}{l}1.000^{* * *} \\
(0.678)\end{array}$ & $\begin{array}{c}0.910 \\
(0.985)\end{array}$ \\
\hline Personal limitations & $\begin{array}{l}-0.471 \\
(0.336)\end{array}$ & $\begin{array}{l}-0.271 \\
(0.236)\end{array}$ \\
\hline External limitations & $\begin{array}{l}-0.012 \\
(0.539)\end{array}$ & $\begin{array}{l}-0.012 \\
(0.539)\end{array}$ \\
\hline Risk & $\begin{array}{l}1.416^{*} \\
(0.322)\end{array}$ & $\begin{array}{l}1.236^{*} \\
(0.401)\end{array}$ \\
\hline Constant & $\begin{array}{l}-2.135 * \\
(0.922)\end{array}$ & $\begin{array}{l}-3.035^{*} \\
(1.972)\end{array}$ \\
\hline $\begin{array}{l}\text { Wald chi }{ }^{2}(13) \\
\text { Pseudo } \mathrm{R}^{2}\end{array}$ & $\begin{array}{l}40.99 \\
0.1559\end{array}$ & $\begin{array}{l}42.29 \\
0.1459\end{array}$ \\
\hline $\begin{array}{l}\text { Notes: } \\
{ }^{*} 1 \% \text { significant, }{ }^{* *} 5 \% \text { significant; }{ }^{* * *} 10 \% \text { significant. } \\
\text { When nothing is mentioned it means no statistical significance }\end{array}$ & & \\
\hline
\end{tabular}

Table 3: Determinants of students' entrepreneurial propensity. 
Citation: Silva A, Nobre N (2018) Students' Entrepreneurial Propensity: An Exploratory Study from a Portuguese Polytechnic School. J Entrepren Organiz Manag 7: 226. doi: 10.4172/2169-026X.1000226

Page 6 of 6

and $40 \%$. In order to evaluate the importance of different factors in explaining students' entrepreneurial propensity, we applied a logistic regression model.

The results obtained showed us that the most influential factors in explaining student's entrepreneurial propensity are both the Course Year and the Risk propensity. Also very important are some "external" factors such as: Entrepreneur's example, the previous experience as a manager and the participation in Erasmus exchanges. Among the demographic factors, being a male student instead of a female also proved to be a relevant factor.

As for the importance of the course in which the student is enrolled, we observed that students in the management area are more likely to be future entrepreneurs, thus proving the idea that courses that offer more information and training in entrepreneurship increase students' positive attitudes towards this issue. This is an important corollary as it means schools have instruments to boost students' entrepreneurial propensity with positive consequences both to students and to society.

However, it is important to recognize that this study presents some limitations, especially given the fact that it is just a single wave of surveys and does not provide yet a view about the evolution of the entrepreneurial propensity that each student may experience during his/her academic life to be observed.

\section{References}

1. Reynolds PD, Hay M, Bygrave WD, Camp SM, Autio E (2000) Global Entrepreneurship Monitor: 2000 Executive Report, Kansas City: Kauffman Center for Entrepreneurial Leadership.

2. ILO (2013) Global employment trends for youth 2013: a generation at risk. International Labour Office (ILO). Geneva.

3. Gartner WB (1985) A conceptual framework for describing the phenomenon of new venture creation. Academy of Management Review 10: 696-706.

4. Zampetakis LA, Gotsi M, Andriopoulos C, Moustakis V (2011) Creativity and entrepreneurial intention in young people: Empirical insights from business school students. The International Journal of Entrepreneurship and Innovation 12: $189-199$

5. European Comission (2008) Entrepreneurship in higher education, especially within non-business studies, Brussels: Final Report of the Expert Group.

6. Arenius P, Minniti M (2005) Perceptual Variables and Nascent Entrepreneurship. Small Business Economics 24: 233-247.

7. Gerry C, Marques C, Nogueira F (2008) Tracking student entrepreneurial potential: personal attributes and the propensity for business start-ups after graduation in a Portuguese university. Problems and Perspectives in Management 6: 45-53.

8. Kirzner IM (1973) Competition and Entrepreneurship. Chicago: University of Chicago Press

9. Baron RA (2000) Psychological perspectives on entrepreneurship: cognitive and social factors in entrepreneur's success. Current Directions in Psychological Science 9: 15-18.

10. Kihlstrom RE, Laffont JJ (1979) A general equilibrium entrepreneurial theory of firm formation based on risk aversion. Journal of Political Economy 87: 719748

11. McClelland DC (1961) The achieving society. The Free Press.

12. Casson MC (1982) The Entrepreneur: An Economic Theory. Oxford: Martin Robertson.

13. Ajzen I (1991) The theory of planned behavior. Organizational Behavior and Human Decision Processes 50: 179-221.

14. Henderson R, Robertson M (2000) Who Wants To Be an Entrepreneur? Young Adult attitudes to entrepreneurship as a career. Career Development International: 5: 279-287.

15. Krueger NF, Reilly MD, Carsrud AL (2000) Competing models of entrepreneurial intentions. Journal of Business Venturing 15: 411-432.

16. Shapero A (1984) The Environment for Entrepreneurship, C.A. Kent, ed., Lexington Books, Lexington, Ma., 1984, pp. 21-40.

17. Castrogiovanni GJ (1996) Pre-Startup Planning and the Survival of New Small Businesses: Theoretical Linkages. Journal of Management 22: 801-822.

18. Robertson D (2004) Stress and the entrepreneur. Bibby Financial Services.

19. Gnyawali DR, Fogel DS (1994) Environments for Entrepreneurship Development: Key Dimensions and Research Implications. Entrepreneurship: Theory and Practice 18: 43-62.

20. Franke N, Luthje C (2004) Entrepreneurial Intentions of Business Students: A Benchmarking Study. International Journal of Innovation and Technology Management 1: 269-288.

21. Gurol Y, Atsan N (2006) Entrepreneurial characteristics amongst university students: some insights for enterprise education and training in Turkey. Education + Training 48: 25-39.

22. Scott MG, Twomey DF (1988) The long-term supply of entrepreneurs: students' career aspirations in relation to entrepreneurship. Journal of Small Business Management 26: 5-13.

23. Wang CK, Wong P (2004) Entrepreneurial interest of university students in Singapore. Technovation 24: 163-172.

24. Fafaliou I (2012) Students' propensity to entrepreneurship: an exploratory study from Greece. International Journal of Innovation and Regional Development 4 : 293-313.

25. Jones C (2010) Entrepreneurship education; revisiting our role and its purpose. Journal of Small Business and Enterprise Development 17: 500-513.

26. Nabi G, Linan F (2011) Graduate entrepreneurship in the developing world: intentions, education and development. Education+Training 53: 325-334.

27. Rosario A (2007) Propenso ao empreendedorismo dos alunos finalistas da Universidade do Porto, Faculdade de Engenharia, Universidade do Porto, Tese de Mestrado em Inovacao e Empreendedorismo Tecnologico.

28. Luthje C, Nikolaus F (2003) The 'Making' of an Entrepreneur: Testing a Model of Entrepreneurial Intent among Engineering Students at MIT. R\&D Management 33: $135-147$. 